\title{
Optimization management for chili (Capsicum annum L.) production in agroforestry system with Coconut (Cocos Nucifera L.) on local protected coastline areas
}

\author{
Dina Ruslanjari ${ }^{*}$, Priyono Suryanto ${ }^{2}$ and Taufan Alam ${ }^{3}$ \\ ${ }^{1}$ The Graduate School of Universitas Gadjah Mada, Yogyakarta \\ 2Departement of Silviculture, Faculty of Forestry, Universitas Gadjah Mada, Yogyakarta \\ ${ }^{3}$ Departement of Agronomy, Faculty of Agriculture, Universitas Gadjah Mada, Yogyakarta
}

Received: 2020-05-26

Accapted: 2020-11-25

Keywords:

agroforestry phase;

chili; coastline area;

land evaluation

Correspondent email:

dienarus@ugm.ac.id

\begin{abstract}
Bugel coastline areas have the potential for horticulture commodities development. This study's objectives were mapping protected Bugel coastline areas, land evaluation, and yield response of chili in an agroforestry system with coconut trees on Bugel coastline areas. The research was conducted during April-July, 2015, in Bugel coastline areas, Panjatan District, Kulonprogo Regency, Special Province of Yogyakarta. The first stage was the literature study and field mapping by BING satellite imagery. The second method was an actual and potential land evaluation using the FAO version, Sys criteria, and Sys limitation. The third method was using a randomized complete block design (RCBD) with three blocks as replications. The results showed that a local protected coastline area allowed for the agriculture and forestry crops is $>200$ meters from the furthest tide point. The actual and potential land evaluation in all agroforestry phases were not suitable and marginally suitable. The initial phase showed the highest fresh fruit weight by 100.30 grams/plant, compared with the intermediate and advanced phases by 88.13 grams/ plant 71.54 grams/plant.
\end{abstract}

2020 by the authors. Licensee Indonesian Journal of Geography Indonesia.

This article is an open access article distributed under the terms and conditions of the Creative Common

Attribution(CC BY NC) licensehttps://creativecommons.org/licenses/by-nc/4.0/,

\section{Introduction}

The ring one transmigration model (local transmigration) in Kulon Progo Regency was conducted to manage housing and people relocation from vulnerable disaster areas of Samigaluh, Kalibawang, Kokap, Grimulyo, Pengasih, and Nanggulan Districts. Wibawanti \& Harjiyatni (2008) found that $17.6 \%$ of people follow the transmigration program to gain productive land access. Most land used in Bugel Village is $56.05 \%$ of dunes. This land is mostly used for farming chili, eggplant, watermelon, and other horticulture commodities. The distance of 'villagers' houses to the furthest tide point is varied. There are 17 houses located at 0-100 meters from the furthest tide point and 37 houses at 101-200 meters. Therefore, the local farmer who gains profit from cultivating in the local protected area should be stopped to maintain the environmental sustainability. According to regional regulation about coastal border No.4/2009 of Kulon Progo, the coastal border is 200 meters from the furthest tide point towards land. The farmer has used this coastal border to produce agriculture yields since 2003 and no longer according to Regional Regulation of Kulon Progo No.1/2012 regarding spatial planning for 2012-2032 (Kulon Progo Region Government, 2012; Michniewicz, 2013).

One alternative to horticulture commodities development is utilizing space between the coconut agroforestry system in Bugel coastline areas. Agroforestry is balancing the ecosystem of forest conditions that keep damaging all the time, while the practice of cultivating trees outside the forest continues to thrive, otherwise known as the 'trees outside the forest'. Agroforestry can also be categorized into either simultaneous or sequential systems or practices (Wangpakapattanawong et al., 2017).

The mechanisms by agroforestry systems contribute to biodiversity. In general, agroforestry is 1). Help reduce natural habitat conservation by providing a more productive, sustainable alternative to traditional agriculture systems that may involve clearing natural habitat, and 2). Agroforestry helps conserve biological diversity by providing other ecosystem services such as erosion control and water recharge, thereby preventing the degradation and loss of surrounding habitat (McNeely \& Schroth, 2006; Jose et al., 2006; Hervey et al., 2006). The coastal landscape is scarcely utilized for crop production due to the inherently low soil fertility, nutrient imbalance, and water deficit, severely inhibiting crop growth (Roslan et al., 2011).

The study consists of three stages, namely: 1.) The mapping of protected Bugel coastline areas, 2.) Land evaluation of chili under coconut trees stands in Bugel coastline areas and 3.) The response of chili production in an agroforestry system with coconut trees at coastline areas. This 
research found strategic cultivation to prevent farmers from violating land regulation by providing better land management. The availability of coconut stands can be utilized to grow chili and transfer cultivation areas to permitted and safety zone.

\section{The Methods}

The research was conducted during April-July, 2015, in Bugel coastline areas, Panjatan District, Kulonprogo Regency, Special Province of Yogyakarta. This area is located $\pm 46 \mathrm{~km}$ to the south-west of Yogyakarta City.

\section{Experimental Design}

The first stage of this study was used literature study and field mapping (including using Bing satellite imagery), while the second method was conducted to evaluate the actual and potential land using the FAO version, Sys criteria, and Sys limitation. The third study stage was conducting a randomized complete block design (RCBD) with three blocks as replications. The factor was agroforestry phase consisted of the initial phase, intermediate phase, and advanced phase.

\section{Environment Variable}

The environment observation was the mean temperature, annual rainfall, soil drainage, soil texture, soil depth, cation exchange capacity, $\mathrm{pH} \mathrm{H}_{2} \mathrm{O}$, base saturation, c-organic, salinity, total nitrogen, available of phosphorus, available of potassium, slope, surface stoniness, flooding hazard, and erosion hazard. The environment observation was carried out at the research site, at the General Soil, Faculty of Agriculture, Universitas GadjahMada, Special Province of Yogyakarta, Indonesia.

\section{Chili Variable}

The observation of chili was total dry weight per plant and fresh fruit weight per plant. Total dry weight per plant was dried under the sunlight to the $11 \%$ moisture level.
Statistical Approach

The local protected coastal area's measurement is done by determining the furthest tide point from sea level, then draw a straight line towards the land to the extent of 200 meters, and the survey checked the field.

The actual and potential land evaluation is based on the FAO version, SYS criteria, and SYS limitation. The data analysis of the second study use matching analytical approach FAO version, SYS criteria, and SYS limitation by comparing the classification of chili crop requirement, which obtained from the literature with land quality by using the matching table (Table 1 and Table 2) (Sys et al., 1993).

The third study's approach was used as a One-way Analysis of Variance (ANOVA) a 5\% to test for the chili variable in each agroforestry phase. The models must be evaluated so that assumptions can be fulfilled. The normality test was carried out using the Kolmogorov test \& Q-Q plot (Mocanda et al., 2014). The separation of means was subjected to the LSD Fischer test a 5\% (Hinkelman \& Kempthorne, 2008).

\section{Results and Discussion}

Based on results toward the actual conditions of land use in the Bugel coastline area shows that land is mostly dominated by the farm (312.91 ha), a moor (187.64 ha), and irrigated rice fields (110.80 ha). The development of horticultural commodities is currently developed on the moor (rainfed) and rice fields irrigated by joint and several wells.

Based on the Special Province of Yogyakarta Regulation Number 2 of 2010 on Spatial Planning of Special Region of Yogyakarta Province and Local Regulation Kulon Progo Regency Number 4 of 2009 about local protected coastline areas, land that could be used for the development of agriculture, plantation, forestry and settlements is 200 meters from furthest tide point (Yogyakarta City Government, 2010; Kulon Progo Region Government, 2012) (Figure 1). Consequently, zone $\leq 200$ meters or approximately 38.91 ha

Table 1. Relationship between levels of limitation/land limiting with crop requirement

\begin{tabular}{ll}
\hline \multicolumn{1}{c}{ Limitation } & Crop Requirement Class \\
\hline $0=$ None Limitation & S1 = Highly Suitable \\
$1=$ Slight Limitation & S2 = Moderately Suitable \\
$2=$ Moderate Limitation & S $3=$ Marginally Suitable \\
$3=$ Strong Limitation & $\mathrm{N}=$ Currently not Suitable, could be improved \\
\hline
\end{tabular}

Source: Sys et al. (1993)

Table 2. Crop requirement class criteria

\begin{tabular}{ll}
\hline \multicolumn{1}{c}{ Crop Requirement Class } & \multicolumn{1}{c}{ Land Criteria } \\
\hline S1 $=$ Highly Suitable & Land without limiting factor or only having $\leq 4$ S2 \\
S2 $=$ Moderately Suitable & Land with more than 4 S2 and/or $\leq 3 \mathrm{~S} 3$ \\
S3 $=$ Marginally Suitable & Land with more than $3 \mathrm{~S} 3$ and/or $\leq 3 \mathrm{~N}$ \\
$\mathrm{~N}=$ Currently not Suitable & Land with more than $3 \mathrm{~N}$ \\
\hline
\end{tabular}

Source: Sys et al. (1993) 
of land should be natural without any form of land use, such as agricultural settlements and plantations. Referring to the above statements, a building with \pm 1 ha is located in a local protected coastline area and farmland use with \pm 23.87 ha. Hence, the development of agriculture and plantation land in the Bugel coastline area is directed toward developing agroforestry systems in the coconut-based plantation area.

Land under-stands of coconut trees is the potential for the growth of horticultural crops. The reason is understood of coconut trees area minimally utilized for the development of horticultural crops commodity. One of the horticultural crops grown by farmers in the Bugel area is chili. Characteristics of red chili plants such as C3 types of the plant can still adapt well in shaded conditions until certain perimeters, thus likely developing coconut under-stands in agroforestry systems.

Agroforestry systems are characterized by the presence of tree components and seasonal crops in the same space and time. These conditions resulted in lessening the field for seasonal crop cultivation due to crown development. As a result, agroforestry system space spatial dynamics are determined by characteristics of the constituent components and tree cultivation systems (silviculture aspect); this circumstance is the coconut tree.

The dynamics of constituent components followed by the spatial dynamic effect on the resources are dynamic in an agroforestry system. Resources dynamics will be further seen in the resources sharing system, especially between trees, trees with seasonal crops, and seasonal crops. Resources on the ground (sunlight) vary from time to time to give light capture by seasonal crops, which are also dynamic (Suryanto et al., 2020). Therefore, based on that, coconut land understands that have the potential for chili growth should be grouped by evaluating the crop requirement and chili performance assessment based on light gradient differences under-stands of coconut. There should be divided into three strata, such as initial agroforestry phases (shade intensity 0$30 \%$ ), intermediate (shade intensity 31-60\%), and advanced (shade intensity $>60 \%$ ).
Generally, the status of soil fertility is categorized as very low to moderate. Actual land conformity results in the initial agroforestry phase for chili based on the FAO version, including in $\mathrm{Nr}$ sub-class by inhibitor factor such as rooting medium (r), which land drainage in the speedy category sandy soil texture based on the Sys version included in S3 sub -class with the level of limitation of 11.

Sandy soils have a wide range of limiting factors for deficiencies, acidity, and low water holding capacity, also susceptible to wind erosion. Together with low organic matter, the sandy often leads to a low water holding capacity and high infiltration rate, representing significant challenges for agriculture (Amooh and Bonsu, 2015).

Freeze and Cherry (1979) explains that the grain size distribution of granular soils affects their permeability. Onur added that well-graded soils have smaller grains that tend to fill the voids between larger grains, different from poorlygraded soils with higher porosity and permeability values. High final infiltration rates are responsible for actual water losses in conveyance systems and the field. Alhammadi and Al-Shrouf (2013) explain that high infiltration rates may be an essential constraint to efficient surface irrigation schemes. High infiltration rates also affect the soil structure in that often, the clay particles in the upper layers are conveyed to deeper layers where they accumulate and form a less permeable horizon.

Overall, the initial agroforestry phase has a better crop requirement level than intermediate and advanced phases concerning nutrient retention and availability of a nutrient (included in the S1 sub-classes). Due to coastal sand land in the initial agroforestry phase, it is more used as an agricultural area for seasonal crop cultivation. As a result, organic material and fertilizer application input is higher than organic material, and fertilizer application input is higher than land in the intermediate and advanced phase category.

Chili growth in all agroforestry phases (initial, intermediate, and advanced) has a problem concerning

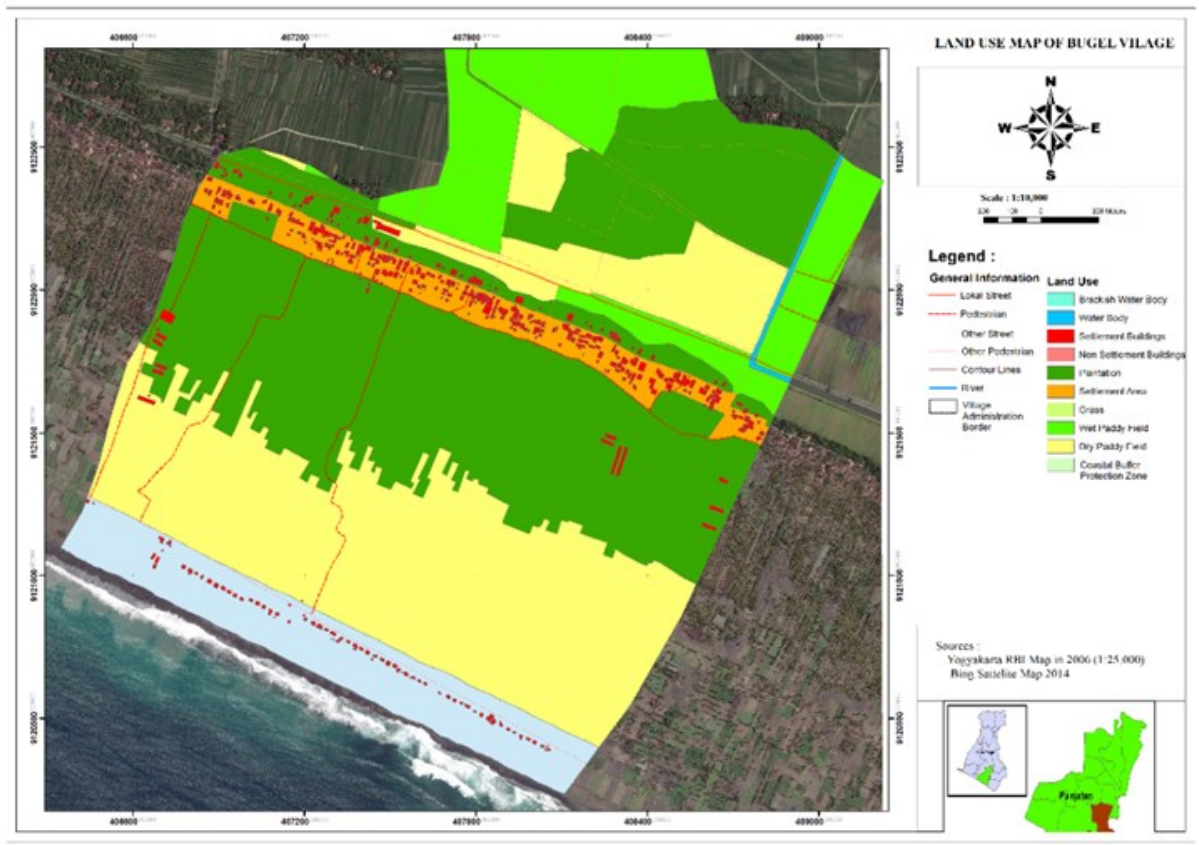

Figure 1. Land Use Map Based on Local Protected Coastline Area 
Table 3. Total dry weight (grams/plant) and fresh fruit weight (grams/plant)

\begin{tabular}{lcc}
\hline \multicolumn{1}{c}{ Agroforestry Phase } & Total Dry Weight & Production \\
\hline Initial & $200.87^{\mathrm{a}}$ & $100.30^{\mathrm{a}}$ \\
Intermediate & $180.33^{\mathrm{b}}$ & $88.13^{\mathrm{b}}$ \\
Advanced & $137.13^{\mathrm{c}}$ & $71.54^{\mathrm{c}}$ \\
Mean & 172.78 & 86.66 \\
$\mathrm{CV}(\%)$ & 0.99 & 0.95 \\
\hline
\end{tabular}

Numbers followed by the same letter in the same row were not significantly different by the LSD Fischer test $(\mathrm{p}<0.05)$.

temperature $(\mathrm{t})$ and rooting medium $(\mathrm{r})$. Temperatures in the Bugel coastline area belong to S3 class. The temperature factor often limits plant growth, and the magnitude of optimum temperature is not equal for each type and plant species. The temperature of almost all plants during the physiological process (from phenotypic development to catalyzed reaction on the enzymatic basis and the transportation of cell membranes for physical processes), such as transpiration, respiration, and volatilization, need specific compounds (Mondal et al., 2016).

Sandy's texture and fast drainage are becoming the main problems. The sand fraction is generally dominated by medium-sized sand (0.5-0.75 $\mathrm{mm}$ of effective diameter). Vengadaramana and Jashothan (2012) explain that waterholding capacity measures water quantity to access a crop effectively. The available water for crop growth is the difference between the water content at field capacity and the permanent wilting point. Field capacity is defined as the water content at which internal drainage becomes practically negligible, while the permanent wilting point is determined as the soil water content at a matric potential of $-1,500 \mathrm{kPa}$.

The groundwater in this area is shallow with good groundwater quality. Jayasingha (2011) proposes that coastal shallow sandy aquifers are highly studied worldwide since they are very good freshwater storages. The use of groundwater of coastal aquifers has rapidly increased during the past few decades to urbanization, industrialization, and agricultural activities. Coastal sandy aquifers are also vulnerable to salinization due to many reasons such as seawater intrusion, extensive extraction of groundwater due to agricultural practices, leaching of deicing salts and high rate of evapotranspiration and contamination of natural salts in aquifer media (Kim \& Yun 2005; Milnes et al., 2006; Park et al., 2005; Roshental et al., 1992; Sherif \& Singh, 2002). Besides, intermediate and advanced phases of agroforestry have the advantage of coconut. Like a windbreaker, the tree has a role in reducing the wind speed, which brings with particles of salt.

The result of the assessment in chili crop performance (on each coconut phase) shows real differences in chili production's total dry weight (Table 3). The initial Agroforestry phase showed the highest results, followed by the intermediate and advanced agroforestry phases. It is caused by a light gradient factor and the level of soil fertility in each phase.

Light intensity is a significant determinant of photosynthesis and plant growth. Under a low-light regime, both the photosynthetic rate and crop productivity are low (Biswal et al., 2012). The decrease in quantity and quality of sunlight will affect the plant physiological processes, namely the opening and closing of stomata, transpiration rate, photosynthesis, and stomata conductivity dynamics. Petrova (2012) describes that plants grown under high light intensity have more stomata per $1 \mathrm{~mm} 2$ than plants grown under low light intensity.

\section{Conclusion}

The local protected coastline area allowed for the agriculture and forestry crops is $>200$ meters from the furthest tide point. The results of actual and potential land evaluation based on FAO version, Sys criteria, and Sys limitation were $\mathrm{Nr} / \mathrm{S} 3 / 11$ and S3twr/S3/8 (initial phase), $\mathrm{Nr} /$ $\mathrm{S} 3 / 17$ and S3twr/S3/8 (intermediate phase), and $\mathrm{Nr} / \mathrm{S} 3 / 17$ and S3twr/S3/8 (advanced phase). The initial phase showed the highest fresh fruit weight (100.30 grams/plant), compared with the intermediate phase (88.13 grams/plant) and advanced phase (71.54 grams/plant). The improvement of actual to be a potential land evaluation and chili production with fertilizer application. Besides, manure and other organic soil amendments can be used as fertilizer.

Control-tide mark for conservation land should be according to the Regional Regulation No. Kulonprogo 4 in 2009, a derivative of the Spatial Law No. 26 of 2007, also the Law on Disaster Management No. 24 of 2007, is against the threat of tsunami and abrasion. Translocate agricultural land to productive dry land, plants according to land, and microclimate conditions (innovation and technology).

\section{Acknowledgments}

The authors would like to express their profuse thanks to the Directorate of Indonesian Higher Education 2015, which has funded this research through the grant-in-aid scheme.

\section{References}

Alhammadi, M. S., \& Al-Shrouf, A. (2013). Irrigation of sandy soils, basic and scheduling. In Tech. http:// dx.doi.org/10.5772/55117.

Amooh, M. K., \& Bonsu, M. (2015). Effects of soil texture and organic matter on evaporative loss of soil moisture. Journal of Global Agriculture and Ecology, 3(3), 152-161. https:// www.researchgate.net/publication/281149494

Biswal, A. K., Pattanayak, G. K., Pandey, S. S, Leelavathi, S., Reddy, V. S., Govindjee, \& Tripathy, B. C. (2012). Light intensitydependent modulation of chlorophyll $b$ biosynthesis and 
photosynthesis by over expression of chlorophyllide a oxygenase in tobacco. Plant Physiology, 159, 433449. https://doi.org/10.1104/pp.112.195859.

Fageria, N. K., Carvalho, G. D., Santos, A. B., Ferreira, E. P. B., \& Knupp, A. M. (2011). Chemistry of lowland rice soils and nutrient availability. Communication in Soil Science and Plant Analysis, 42, 1913-1933.

Freeze, R. A., \& Cherry, J. A. (1979). Groundwater. Englewood Cliffs, New Jersey :Prentice Hall Inc, US.

Harvey, C. A, Gonzales, J. G., \& Somarriba, E. (2006). Dung beetle and terrestrial mammal diversity in forest, indigenous agroforestry systems and plantain monocultures in Talamanca, Costa Rica. Biodivers Conservation, 15, 555585. https://doi.org/10.1007/s10531-005-2088-2.

Hinkelman, K., \& O. Kempthorne. (2008). Design and analysis of experiments. $2^{\text {nd }}$ Edition. John Wiley and Sons, USA.

Jayasingha, P., Pitawala, A., \& Dharmaguna W. H. A. (2011). Vulnerability of coastal aquifers due to nutrient pollution from agriculture Kalpitya, Sri Lanka. Water Air Soil Pollution, 219, 563-577. https://doi.org/10.1007/s11270010-0728-y.

Jose, S., Gillespie, A. R., \& Pallardy, S. G. (2004). Interspecific interactions in temperate agroforestry. Agroforestry System, 61, 237-255. https://doi.org/10.1023/ B:AGFO.0000029002.85273.9b.

Kim, K., \& Yun, S. T. (2005). Buffering of sodium concentration by cation exchange in the groundwater system of a sandy aquifer. Geochemical Journal, 39, 273-284. https:// doi.org/10.2343/geochemj.39.273.

Kome, G. K., Enang, R. K., Tabi, F. O., \& Yerima, B. P. K. (2019). Influence of clay minerals on some soil fertility attributes: a review. Journal of Soil Science, 9, 155-188.

Kulon Progo Region Government. (2012). Regional Regulation of Kulon Progo No.1/2012 regarding spatial planning for 20122032. Kulon Progo Region Government, , Special Province of Yogyakarta, Indonesia. https://peraturan.bpk.go.id/ Home/Details/16103.

McNeely, J. A., \& Schroth, G. (2006). Agro-forestry and biodiversity conservation-traditional practices, present dynamics and lessons for the future. Biodiversity Conservation, 15, 549554. https://doi.org/10.1007/s10531-005-2087-3.

Michniewicz, R.P. (2013). Protecting our coastline. Engineering News and Information, Coastal Engineering Company, Inc., USA.

Milnes, E., Yeo, D., Renard, P., Hunkeler, D., Schnegg, P., \& Bourret, F. (2006). Hydrogeochemical and hydrogeological investigation in the Akrotiri aquifer: identification of multiple salinisation processes and implementation criteria for monitoring networks. Proceedings of the $1^{\text {st }}$ SWIMSWICA Meeting, September 2006.

Mocanda, M. P., Gabriels, D., \& Cornelis, W. M. (2014). Datadriven analysis of soil quality parameters using limited data. Geoderma, 235-236, 271-278. https://doi.org/10.1016/ j.geoderma.2014.07.014.

Mondal, S., Ghosal, S., \& Barua, R. (2016) Impact of elevated soil and air temperature on plants growth, yield and physiological interaction: A critical review. Scientific Agriculture, 14(3), 293-305.

Nguyen, H. Q. (2010). Long-terms effects of land application of poultry manure on crop production, and soil and water quality under a corn-soybean rotation system in Iowa. Graduate Theses and Dissertations, Iowa State University. https://lib.dr.iastate.edu/etd/11718/.

Park, S., Yu, S., Chae, C., Yoo, I., Skin, K., \& Heo, C. (2005). Regional hydrogeochemical study on salinisation of coastal aquifer, western coastal area of South Korea. Journal of Hydrology, 313(3-4), 182-194. https://doi.org/10.1016/ j.jhydrol.2005.03.001.

Petrova, Y. (2012). The affect of light intensity on the stomatal density of lavender (Lavanda angustifolia). Young Scientist
Journal, $12, \quad 89-93 . \quad$ https://doi.org/10.4103/09746102.105078.

Region Development Planning Agency. (2010). Regional spatial plan for special province of Yogyakarta 2009-2029. Region Development Planning Agency, Special Province of Yogyakarta, Indonesia.

Rogers, D. H., Aguilar, J., Kisekka, I., Barnes, P. L., \& Lamm, F. R. (2014). Soil, Water, and Plant Relationships. Kansas State University Research and Extension, USA.

Rosenthal, E., Vinokurov, A., Ronen, D., Magaritz, M., \& Moshkovitz, S. (1992). Anthropogenically induced salinization of groundwater: A case study from the coastal Water Air Soil Pollut plain aquifer of Israel. Journal of Hydrology, 270(1-2), 27-38. https://doi.org/10.1016/01697722(92)90038-G.

Roslan, I., Shamsudi, J., Fauziah., C. I., \& Anuar, A. R. (2011). Fertility suitability of spodosols formed on sandy beach ridges interspersed with swales in the Kelantan-Trengganu plains of Malaysia for kenaf production. Malaysian Journal of Soil Science, 15, 1-24.

Sherif, M. M., \& Singh, V. P. (2002). Effect of Groundwater Pumping on Seawater Intrusion in Coastal Aquifers. Agricultural Sciences, 7(2), 61-67. https://doi.org/10.24200/ jams.vol7iss2pp61-67.

Suryanto, P., Faridah, E., Triyogo, A., Kastono, D., Suwignyo, B., Nurmalasari, A. I., \& Alam, T. (2005). Designing of soil quality and climate assessment tool for sustainable production of signalgrass (Brachiaria brizantha) silvopasture system in mountain ecosystems. Australian Journal of Crop Science, 14(4), 614-621.

Sys, C., Rans, E. V., Debaveye, J., \& Beernaert, F. (1993). Land evaluation part iiicrop requirement. Agriculture Publication, General Administration for Development Cooporation, Belgia.

Vengadaramana, A., \& Jashothan, P. T. J. (2012). Effect of organic fertilizers on the water holding capacity of soil in different terrains of Jaffna peninsula in Sri Lanka. Journal of Natural Product and Plant Resources, 2(4), 500-503.

Wangpakapattanawong, P., Finlayson, R., Öborn, I., Roshetko, J. M., Sinclair, F., Shono, K., Borelli, S., Hillbrand, A., \& Conigliaro, M. (2017). Agroforestry in rice-production landscapes in Southeast Asia: a practical manual. Food and Agriculture Organization of the United Nations Regional Office for Asia and the Pacific, Bangkok, Thailand \& World Agroforestry Centre (ICRAF) Southeast Asia Regional Program, Bogor, Indonesia.

Wimbawati, E. S., \& Harjiyatni, F. R. (2008). Provision of rights in coastal zone utilization for ring I transmigration in Kulon Progo Regency. Jurnal Mimbar Hukum, 20(1), 179-191.

Yogyakarta City Government. (2010). Special Region of Yogyakarta Regulation Number 2 of 2010 on Spatial Planning of Special Province of Yogyakarta. Yogyakarta City Government, Special Province of Yogyakarta, Indonesia. https:// polpp.jogjakota.go.id/assets/instansi/polpp/files/perda-no.2th_.-2010-4041_.pdf.pdf. 